\title{
Sectoral and Livelihood Vulnerability to Climate Risk in Indian Himalaya: A Case Study of Almora District of Uttarakhand
}

\author{
Ashish Panda, Anil Kumar Gupta, Amarjeet Kaur
}

\begin{abstract}
Climate change impacts the society by aggravating related hazards. India, due to its varied geographical and climatic attributes and diverse socio-economic reasons, faces almost all kinds of disasters distantly or closely related to change in climates. Regions of Indian Himalaya, especially in Uttarakhand, are known to suffer the brunt of climate or water related disasters very frequently e.g. 2013's devastating flash flood at Kedarnath, Uttarakhand. India is a signatory of the Sendai Framework for Disaster Risk Reduction and has hosted the $7^{\text {th }}$ Asian Ministerial Conference on Disaster Risk Reduction (AMCDRR) and organized its $2^{\text {nd }}$ National Platform on Disaster Risk Reduction (NPDRR) during recent years $(2015,2016)$. These policy regimes advocate climate resilient development through policy planning and grassroots implementation of programmes. Objective of this study is to analyze climatic data projections and risks with regard to extreme events in Almora District, Uttarakhand, India, through learning sectoral and livelihood vulnerabilities of this region. Methodology involved policy and vulnerability analysis through structured and semi-structured questionnaires, focus group discussion and shared learning, with key line Departments and key stakeholders. Study revealed a range of precipitation and temperature level changes and linkages with increase in disaster related losses and damages. Key Sectoral Vulnerabilities \& livelihood challenges have been identified in the Almora District. Paper suggests a policy analysis framework and integration of climate resilience and disaster management into development paradigms through plans, policies and processes of key sectors and departments.
\end{abstract}

Key Words: Resilience, Livelihood, Integration, Vulnerability, Sectoral, Adaptation.

\section{INTRODUCTION}

Extreme Weather Events are costing India \$9-10 billion annually. Due to climate change, productivity decrease of major crops could rise to as much as $10-40 \%$ by 2100 , unless farming sector adapts to the climate change induced changes in weather. Adaptation will need different cropping patterns and suitable inputs to compensate yield fluctuations. Dip in agricultural productivity could turn India to be a big importer of milk and pulses in future. (TOI News, August 18, 2017) Climate change, one of the foremost emerging global challenges, is increasingly visible through highly erratic instances of weather deviations and induced extreme events.

Revised Manuscript Received on March 13, 2020.

* Correspondence Author

Ashish Panda*, GGS Indraprastha University School of Environment Management, New Delhi, India. Email: ashish_panda@yahoo.com,

Anil Kumar Gupta, National Institute of Disaster Management, New Delhi, India. Email:anilg.gov.in@gmail.com,

Amarjeet Kaur, GGS Indraprastha University School of Environment Management, New Delhi, India.Email:amarjeet_ip@yahoo.com

(C) The Authors. Published by Blue Eyes Intelligence Engineering and Sciences Publication (BEIESP). This is an open access article under the CC BY-NC-ND license (http://creativecommons.org/licenses/by-nc-nd/4.0/)
Uttarakhand, due to its geographical location and climatic conditions, is extremely vulnerable to changes in climate. Multiple climate hazards range from increased and frequent flooding, incessant rainfalls, flash floods, droughts, landslides, forest fires, hailstorm \& cold waves etc. Monsoon plights in the recent past are examples of climate induced problems. Flash floods of Uttarakhand in June 2013 are one of the significant examples.

Despite Uttarakhand having multiple water reserves including 17 rivers, several snow fed glaciers, and 31 lakes, unsystematic distribution of water and poor management of water resources result in water scarcity in many districts. Frequent landslides damage water pipes and infrastructure. The quality of water, too, has deteriorated in some regions. Communities in the hills are dependent on local springs, which periodically dry up due to lack of recharge during the summer months. Changing patterns of snowmelt and rainfall are impacting the quantity of water available in local sources. (ToI, Jun 4 2017).

Possible impacts of climate change on forest of Uttarakhand might include changing phenological behaviour, upward shift of lowland species, change in nutrient dynamics, and invasion of alien species, changes in forest soil seed bank and frequency and intensity of occurrence of forest fires.

Hailstorm events in high altitude areas of Uttarakhand are also shifting from March to as late as May and these increase damage to various fruit crops at the flowering and early fruit stage. Most glaciers in the Himalayan region are retreating. As such, the normal glacial melt will not be able to contribute to the region's water supply each year. Variations in climate; in the timing, amount, and type of precipitation; and in glacial behaviour and dynamics mean that it is challenging to determine exactly how retreating glaciers will affect water supply in each location (CEDAR, 2015).

Looking at the severity of environmental conditions and the volume of damage that climate induced disasters cause; there is need for better planning and preparedness to deal with new and unforeseen climatic changes in the future. Integration of a climate resilience agenda into developmental goals has the potential to systematically build resilient communities, reduce vulnerability and achieve the desired development goal of sustainable and climateresilient cities. (TERI).

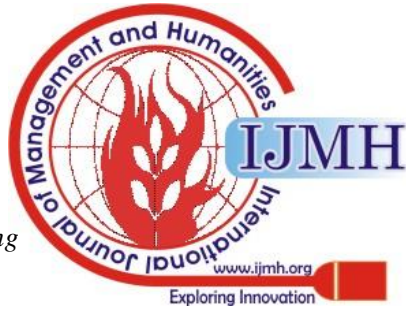




\section{APPROACH \& METHODOLOGY}

Shared Learning Dialogues approach was adopted with the officials of Line Ministries and Departments in Almora. Each Department was involved in such exercise for their opinion on climatic variability in the region. Further, to address the livelihood section, relevant departments, NGOs, as well as the local community were consulted through Focussed Group Discussion mode.

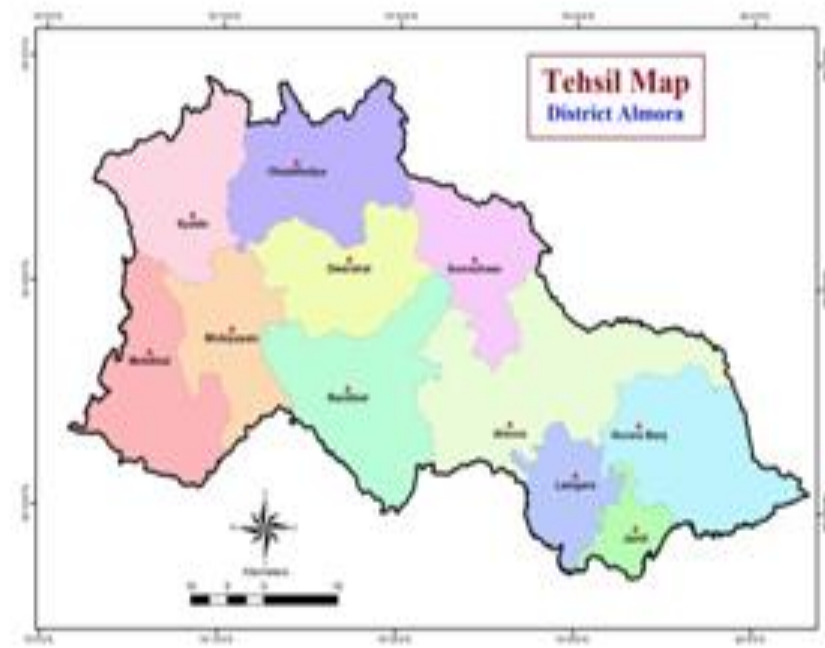

\section{ALMORA DISTRICT: CLIMATE CHANGE AND EFFECTS}

\section{Observations}

\section{A. Climate Change Effects}

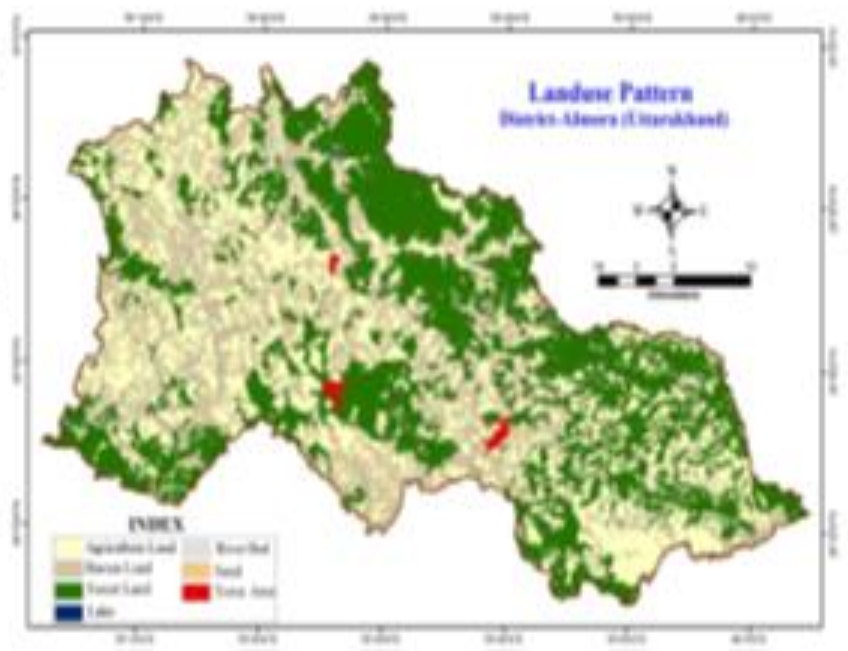

Figure 1. Almora Tehsil Map and Land Use Pattern Map (Source: District Administration, Almora District)

Figure 1 suggests the Tehsil Map of Almora. Situated in the Kumaun region of Uttarakhand, Almora is spread over $3139 \mathrm{Sq} \mathrm{Km}$ area in Uttarakhand, has 11 Tehsils and 11 Development Blocks. There are 2248 revenue villages, 7 police stations and one Municipality Corporation. The population of the District is nearly 622506. 90\% of its population is residing in villages. Figure 1 also gives a fair idea of the land use pattern of Almora. Nearly 50\% land in
Almora is covered by forests. The rest is divided into irrigated agriculture land, non-irrigated agriculture land and very limited town area. There is a strong need to bring in scientific methods in analyzing land use patterns in Almora and to make the best use of it according to the hilly, sloppy and limited agriculture terrain.
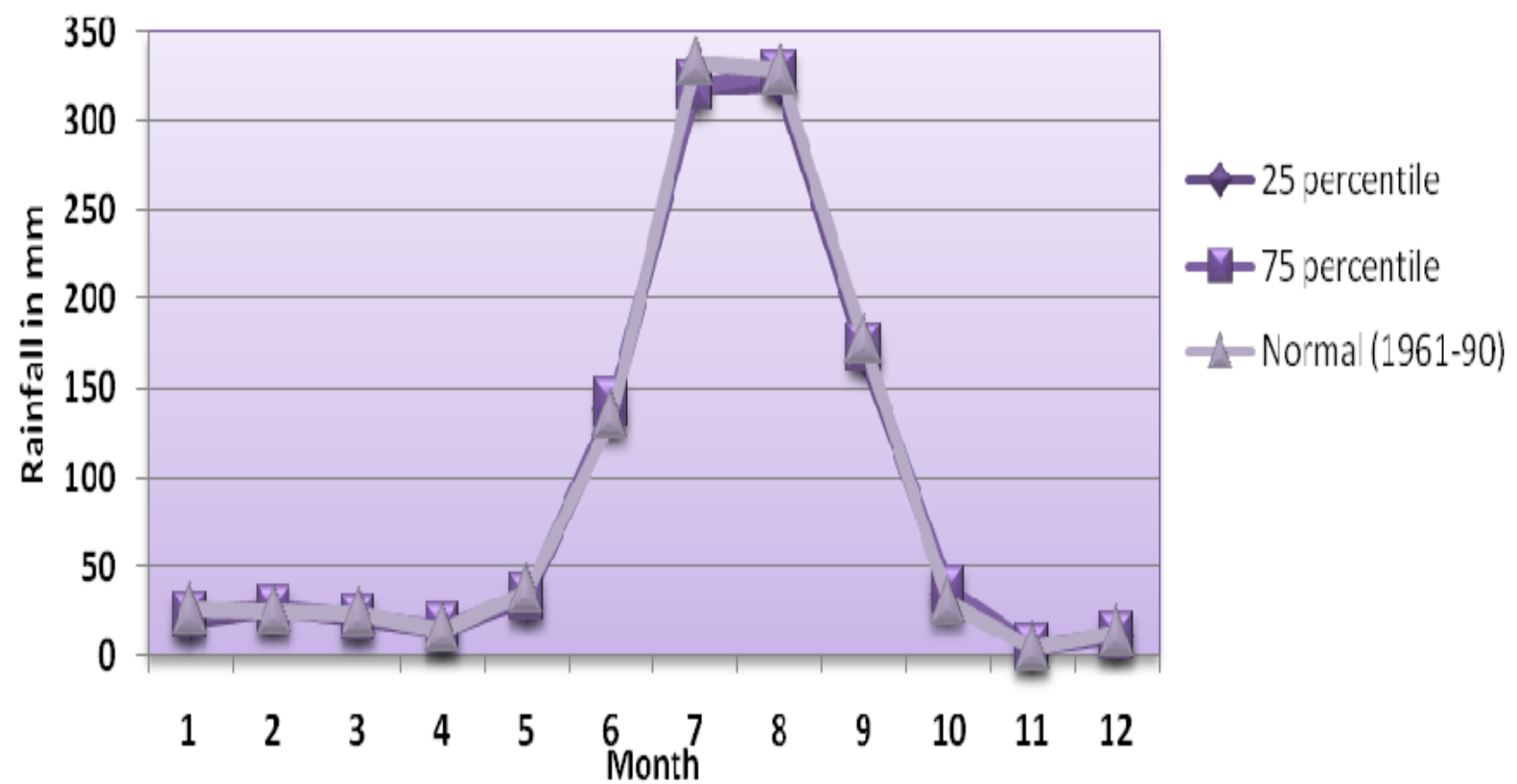

Figure 2. Rainfall Hyetograph of Almora (GEAG, 2016)

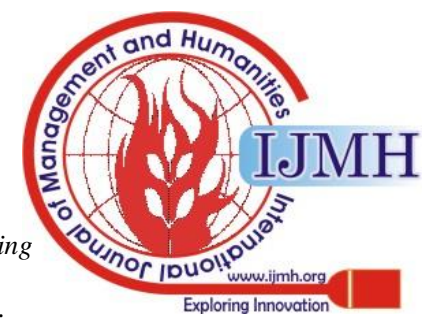


Analysis of annual rainfall in Almora (Fig 2) suggests that the maximum rainfall occurs in the month of July, which constitutes the peak of the annual hyetograph and the months August and September constitute the recession segment of the hyetograph. Of late, the annual hyetograph has been shifted from July to August and since the last two decades there are incidences when the peak of the annual hyetograph is being formed in the month of September. In future the peak of the annual hyetograph may be shifted from August to September. Annual rainfall rhythm is gradually changing in Uttarakhand due to climate change.

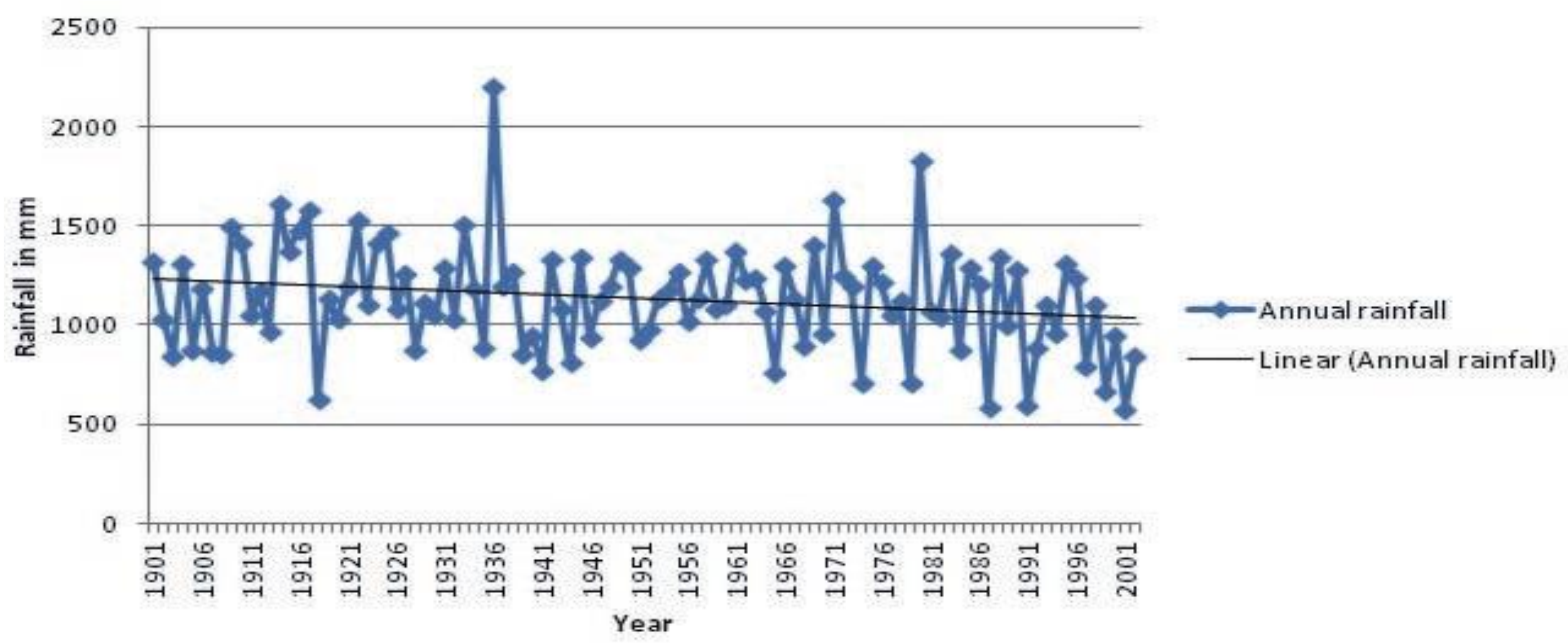

Figure 3. Annual Rainfall Versus Linear Annual Rainfall (Source: District Administration, Almora District)

Figure 3 indicates that overall annual rainfall in Almora has a decreasing pattern. Not only the Annual Rainfall but also the seasonal Monsoon Rainfall (June, July and September) have been reduced over the years in Almora. At the same time, the average rainfall after the Monsoon period (August) has shown increase in occurrence. This might have a great impact over land use, livestock, water availability, forest land etc.

Study of climatic changes in Almora suggests that the average temperature of Almora has increasing trend. The average temperature of Almora, i.e., $17.55^{\circ} \mathrm{C}(1955$ - 2007) has increased up to $0.46^{\circ} \mathrm{C}$. At present, on an average, the Almora Hill Station is receiving $23 \%$ or $244 \mathrm{~mm}$ less annual rain compared to its 53 years annual average rainfall, i.e., $1060 \mathrm{~mm}$.

\section{B. Risk Profile of Almora District}

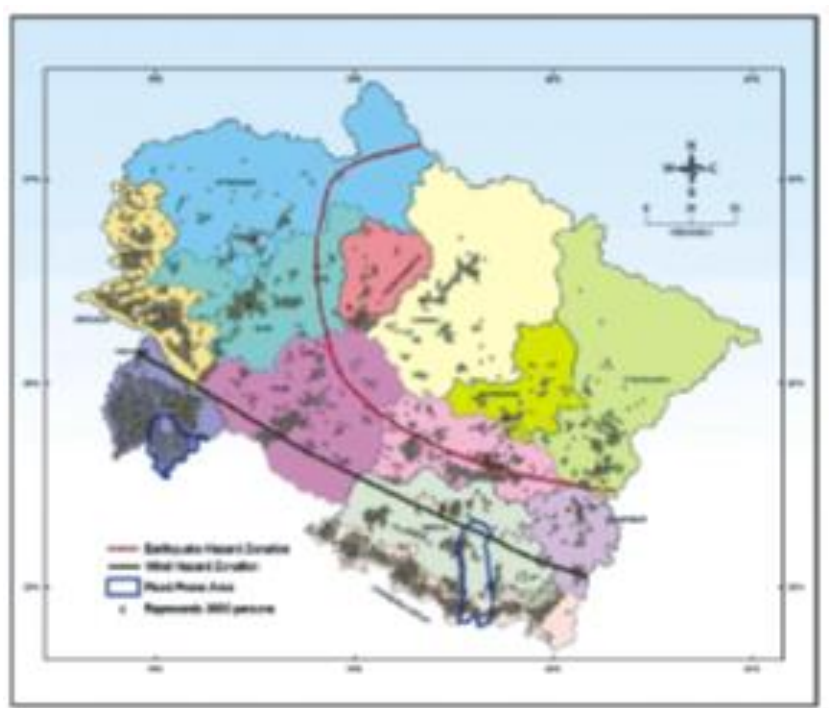

Figure 4. Almora Hazard Zonation (Source: District Administration, Almora)

Figure 4 gives the hazard zonation of Almora. Due to its specific geographical and climatic conditions, it is prone to hazards of earthquakes, landslides, cloudbursts, fires, cold waves, road accidents etc. Kosi, Ramganga and Sarayu in Almora make it susceptible to high risks of floods, and most of its bridges lie at the Earthquake Faults. disasters. Table 1 shows the disaster occurrence probability on monthly basis in this region. Probability of Earthquakes tops the list and may take place in any part of the year. Landslides and Flash floods mostly take place during Monsoon period. Cold waves trouble this region during December January season. Fires do take place during summer period of March to June. 
Sectoral and Livelihood Vulnerability to Climate Risk in Indian Himalaya: A Case Study of Almora District of Uttarakhand

Table 1. Monthly Occurrence Probability of Disasters in Almora

\begin{tabular}{|c|c|c|c|c|c|c|c|c|c|c|c|c|}
\hline Disasters/MOP & Jan & Feb & Mar & Apr & May & June & July & Aug & Sep & Oct & Nov & Dec \\
\hline Flash Floods & & & & & & & & & & & & \\
\hline Earthquakes & & & & & & & & & & & & \\
\hline Fires & & & & & & & & & & & & \\
\hline Cyclones & & & & & & & & & & & & \\
\hline Cold Waves & & & & & & & & & & & & \\
\hline Hail-storm & & & & & & & & & & & & \\
\hline Landslides & & & & & & & & & & & & \\
\hline
\end{tabular}

MOP = Monthly Occurrence Probability

(Source: Deptt. of DM and Revenue, District

Administration Almora, Uttarakhand).

Table 2. Disaster Loss and Damage in Almora District (2010, 2013 \& 2014)

\begin{tabular}{|c|c|c|c|c|c|c|c|c|c|}
\hline \multirow[b]{2}{*}{ Tehsil } & \multicolumn{3}{|c|}{$\begin{array}{c}2010 \text { Cloudburst/Flash flood and } \\
\text { Landslides }\end{array}$} & \multicolumn{3}{|c|}{$\begin{array}{c}2013 \text { Landslides and Heavy } \\
\text { Rainfall }\end{array}$} & \multicolumn{3}{|c|}{2014 Landslides and Heavy Snowfall } \\
\hline & $\begin{array}{l}\text { Human } \\
\text { death }\end{array}$ & $\begin{array}{l}\text { Livestoc } \\
\mathrm{k} \text { death }\end{array}$ & $\begin{array}{c}\text { Housing } \\
\text { damage } \\
\text { (full/partial) }\end{array}$ & $\begin{array}{c}\text { Huma } \\
\mathrm{n} \\
\text { death }\end{array}$ & $\begin{array}{l}\text { Livestoc } \\
\mathrm{k} \text { death }\end{array}$ & $\begin{array}{c}\text { Housing } \\
\text { damage } \\
\text { (full/partial } \\
\text { ) }\end{array}$ & $\begin{array}{l}\text { Human } \\
\text { death }\end{array}$ & $\begin{array}{l}\text { Livestoc } \\
\mathrm{k} \text { death }\end{array}$ & $\begin{array}{c}\text { Housing } \\
\text { damage } \\
\text { (full/partial) }\end{array}$ \\
\hline Almora & 30 & 19 & 959 & 7 & 11 & 122 & 5 & 2 & 87 \\
\hline Bhanoli & 3 & 1 & 197 & 1 & 15 & 143 & 2 & 10 & 115 \\
\hline Jayanti & 3 & 3 & 902 & 0 & 3 & 26 & 0 & 0 & 23 \\
\hline $\begin{array}{l}\text { Semeshw } \\
\text { ar }\end{array}$ & 0 & 10 & 241 & 1 & 3 & 115 & 0 & 4 & 76 \\
\hline Ranikhet & 1 & 12 & 342 & 1 & 3 & 70 & 0 & 0 & 45 \\
\hline Dwarhat & 2 & 6 & 289 & 1 & 0 & 42 & 0 & 1 & 24 \\
\hline $\begin{array}{l}\text { Chaukhut } \\
\text { ia }\end{array}$ & 0 & 5 & 75 & 1 & 25 & 9 & 0 & 0 & 13 \\
\hline $\begin{array}{c}\text { Bhikiase } \\
\mathrm{n}\end{array}$ & 4 & 11 & 430 & 0 & 1 & 99 & 0 & 0 & 56 \\
\hline Sult & 3 & 3 & 423 & 1 & 9 & 43 & 2 & 45 & 13 \\
\hline Total & 46 & 70 & 3858 & 13 & 70 & 669 & 9 & 62 & 452 \\
\hline
\end{tabular}

(Source: District Administration, Almora District)

It may be seen from Table 2 that the Tehsils Almora, Bhanauli and Sult have been affected immensely in disasters in the past few years. Hailstorm in 2014, Landslides and Cold waves of 2013 and Cloudburst of 2010 have brought in lots of damages to the area. For the livestock, the time period of excessive cold (January-February) and Rains (July-September), are very difficult to cope with.

\section{Study of Sectoral Vulnerability}

Through shared learning dialogues with the State Govt. Officials as well as focussed group discussions, key sectors have been identified with their vulnerabilities critical to climate change issues. Important Sectors with their vulnerabilities can be seen as under:-

\section{(a) Agriculture}

- Mostly monsoon dependent agriculture with very less structured irrigation facility.

- Land ownership with men while most of the agriculture activities performed by women.

- Land holdings are mostly small in size and left barren due to unpredictable climate.

- Wild animals menace increasing agri-loss.

- Due to lack of alternate employment, farmer community are forced to migrate to distant places to earn livelihood.
- Due to deforestation, soil erosion taking place during cloud burst and flash flood situations.

- Lack of agriculture extension services and required infrastructure.

- Low inputs and higher agriculture production cost.

- Last mile connectivity issue to remotely placed villages.

\section{(b) Disaster Management}

- Geo-climatic conditions of the region is highly susceptible to disaster risks.

- Population density is high in the cities thereby more pressure on natural resources. Villages are remotely placed thereby creating last mile connectivity issues during disasters.

- Any ecological disturbance in the mountains disturbs the socio-economic fabric of not only the society living in those areas but also the population living downstream.

- Climate change brings related disaster risks of landslides, droughts, cloud bursts, flash floods, receding glaciers, glacial run offs, uneven precipitation, extreme events and loss in wildlife habitats and biodiversity of the region.

Published By:

Blue Eyes Intelligence Engineering 
- Climate change also brings lots of challenges to the food security, water availability and the health concerns of the local community.

\section{(c) Energy}

- Due to receding glaciers, water recharging of rivers and its tributaries is getting affected.

- It also affects the generation of electricity in the hydro power plants due to inadequate flow of water with force. Increasing population has high demands for regular power supply and climate change in a way creates obstacle in this process.

- Climatic disasters also pose threat to power plant infrastructure as well.

- Remotely place villages find it difficult to get power connected due to tough geographical terrain as well as non-economical viability. It also results in their being more vulnerable during the time of extreme events with region getting cut off from the mainstream areas.

\section{(d) Forestry and Biodiversity}

- Due to rise in annual mean temperature, various plant species are moving upwards in height. Local communities have to move to improved agricultural and fodder species.

- Higher altitude biodiversity facing extinction threat due to less area of survival and competition from species coming from lesser heights.

- Climatic variability is changing phenology of species of sal, banj and oak trees.

- Increased chances of Glacial Lake Outburst Floods (GLOFs) would ruin the green pastures.

- Erratic rainfall, surface water run-offs and subsequent drought situations bring down the ground water availability.

- Ever increasing tourism activities are ruining the delicate mountain ecosystem.

\section{(e) Human Health}

- Extreme events are helping growth and spread of disease organisms and vector borne disease at high altitudes. Other than health of the local community, it also contaminates the air, water, agriculture regime as well.

- Thermal extremes are increasing cardiovascular and respiratory diseases.

- Extreme events also bring fatality, injuries, psychological stress and health infrastructure loss thereby stalling the existing health services.

- Increased levels of spores and pollen bring asthma, chronic respiratory issue and allergic conditions.

- Due to lack of availability of fresh water and its further contamination leads to invitation to water borne diseases in high altitudes.

- Traffic and Industrial pollution bring threats of health hazardous gases like sulphur dioxide, nitrogen oxide and ozone.

- Observed changes in incident area and events of vectorborne diseases, e.g. malaria, dengue, chicken-guinea, japanese encephalitis etc.

- Increases incidences of water and food borne disases like diarrhoea and cholera.

- Threatened food security brings malnutrition and hunger thereby impacting natural child growth and development.

\section{(f) Industries and Transport}

- Lack of knowledge about how the industries are affecting the local ecology and environment.
- Congestion of traffic, inadequate space for parking, increased traffic accidents, increased vehicular pollution and insufficient space for motorable raods are critical transport related issues.

\section{(g) Livestock and Animal Husbandry}

- Increase in disease morbidity for livestock.

- Non-availability of feed, fodder and water for livestock.

- Low per animal milk and egg production.

- Man animal conflict over scarce natural resources.

- Time, duration, severity, morbidity and mortality of vector borne diseases are affected due to climate change.

- Lack of veterinary hospitals and facilities therein.

- Poor animal husbandry subsidiary activity.

- Last mile reach connectivity issue to remotely placed villages.

- Wild animal attacks on livestock.

\section{(h) Roads}

- Unscientific construction of roads leads to soil erosion, uprooting of large trees and destruction of lower plants. It adds to siltation in water bodies as well as increases air and water contamination (both surface and groundwater).

- Blasting, excavation and cutting of slopes result in geological disturbances and subsequent landslides, cracks and sinking of mountain.

- Dumping of landslide rubbles and road construction material at insecure places risks the lives of downhill population. It also ruins the natural beauty of mountains. Natural water drainage channel gets blocked and situations of flash floods arise.

- Drastic impact on biodiversity of the area.

- Lots of tree felling changes the biodiversity of the entire region. Rare medicinal plant species get destroyed in the process.

\section{(i) Tourism}

- Climate change affects snowfalls, monsoon and winter rains, biodiversity, availability of fresh water, health system, forest fires and extreme event conditions, thereby, plays a very vital role in tourism sector and its growth.

- Limited infrastructural facilities at various tourist places make these places more vulnerable to climatic disasters. Then tragedies like Kedarnath (2013) bring lots of doubts and fear psychosis in the minds of future tourists for mountains.

- Lack of climatic awareness among local community, tourists and tourism facilitators further worsens the situation.

- Mountain roads being the only lifeline during climatic disasters and lack of other alternate escape routes makes mountain regions very much vulnerable to extreme events.

\section{(j) Urban Development}

- Climate change and extreme events destroy lifeline infrastructure, basic urban services and socio-economic fabric of the society.

- There is huge pressure on the urban infrastructure and services because of unplanned growth of mountain cities.

Published By: Blue Eyes Intelligence Engineering \& Sciences Publication 
- It results in receding forest area, destruction of biodiversity, increased air and water pollution, nonavailability of fresh and hygienic water, increased noise pollution etc.

- Further, the untreated sewage, waste water and solid waste management problems result in contaminated lakes, water bodies and rivers.

\section{(k) Water Resources}

- Changing precipitation and temperature regime brings pressure on environmental and natural resources, water resources, crop production, health conditions etc.

- Availability of surface and ground water gets compromised affecting the local people needs of drinking, domestic and irrigation use of water.

- Hydrological imbalance affects the soil erosion and sedimentation process.

- There are problems of poor water management policy, groundwater legislation and its implementation as well as insufficient water supply system.

- Depleting trend in quantity and quality of natural water resources (srot, naula, dhara etc.) and thereby affecting the rural drinking water supply schemes.

- Due to developmental activities, soil erosion, deforestation, forest fires etc. the land gets naked with less holding/infiltrating capacity thereby allowing surface water overflow and less ground water recharge. It results in flash floods downhills and drought like situations uphills.

\section{LIVELIHOOD RISKS AND ISSUES}

Uttarakhand State, composed of the two broad regions Garhwal and Kumaon, has a geographical inequality between the hills and the plains. Most of the growth due to industrialization has been restricted to the districts in plains. The hill region districts are less developed in terms of infrastructure, i.e., electricity, roads and irrigation, leading to increasing disparity with respect to income and livelihood between the hills and the plains.

Agriculture Dependency:- 3/4 the population depends on agriculture for livelihood. The vast natural resources make the state as investment destination, especially for tourism and agriculture and forest-based industries. Uttarakhand is the first state in the country to have created a Tourism Development Board and it is the first Organic State to be called so. (ICRIER, 2008).

Changing Climate:- It brings loss of livelihood capital, changing agro-livestock conditions and emergence of invasive species. Climate change has adverse impact on the livelihoods based on forestry, agriculture, livestock husbandry, Non-Timber Forest Products and medicinal plants. Communities should start growing produces better suited to the changed scenario and market value. (Routela et.al, 2015).

Disillusioned Youth:- Despite vast traditional wisdom, it is critical to not overlook the mindset of the youths. Television, radio, smart phones, and education have broadened their though pattern. The manual and economically un-rewarding labour used in mountain farming is not an appealing future career for them. It is a challenge to find a development strategy that provides the increased income while still protecting the environment. (www.chimalay.org).
Avenues:- The development of agriculture and an agriculture-based system, linked with industries and tourism can be the way forward for sustainable development. Watershed approach may be an efficient way to improve land productivity and sustain it. Quality seeds suitable for hill agriculture and multi-cropping systems combined with animal husbandry through cattle rearing, poultry, fishing, bee-keeping, etc. can be beneficial. Organic farming and agri-based employment opportunities can be encouraged. The processing of fruits and vegetables, vocational training for youths, and banking and insurance in the service sector can provide livelihood security and support (ICRIER, 2008).

\section{LIVELIHOOD OPPORTUNITIES IN ALMORA}

New ways to enhance the income of farmers may be promoted like adopting high-yield varieties of seed, crop diversification, cultivation of medicinal and aromatic plants, change from conventional crops to high-value crops, providing marketing support, promoting the selfemployment generating schemes, involving people in national schemes like MNREGS and IWMP (now PMKSY), etc. (Planning Commission, 2013).

Traditional farming system, identification of wild plant species for their food importance, diversification of food items and value addition in local recipes are very important to secure the food availability (IJNPR, March, 2010). Ecological conversation led technology based interventions have proven effective in enhancing livelihood resilience. An amalgam of traditional and scientific knowledge could prove effective in anticipatory adaptations. Improving current capacities through sustainable management strategies serve as planned adaptations (NIRM workshop, August, 2013).

Integrated Livelihood Support Project (ILSP) has been (July 2013 to March 2019) implemented in 44 blocks of 11 districts of Uttarakhand including Almora. Uttarakhand has the advantage of cooler temperatures at higher altitudes, allowing production of off-season vegetables (OSV), temperate fruits, horticulture, spices, medicinal, aromatic plants and fruit nuts. Tourism is another area with high growth potential (https://ilsp.in).

Rain water harvesting, roads avoiding landslides/tree felling, green buildings, drought resistant seeds which survive with less water, are few adaptation measures being implemented. State Government has set up institutions and promoted programmes to facilitate mainstreaming various adaptation measures, build the resilience of vulnerable communities and households, deepen impacts of national missions and/or provide co-benefits through developmental interventions (UAPCC, 2014).

Community Forestry Councils (Van Panchayats) have been constituted in more than 12,000 villages to carry forward natural resource-based livelihoods programmes, Green India Mission and National Mission for Sustaining Himalayan Ecosystems. Premier Agriculture Universities and ICAR Institutions of Excellence such as G.B. Pant University, Pantnagar and Vivekanand Parvatiya Krishi Sansthan, Almora are engaged in releasing new varieties of seeds for cereals, vegetables and millets, adapted to changed temperatures.

Published By: Blue Eyes Intelligence Engineering

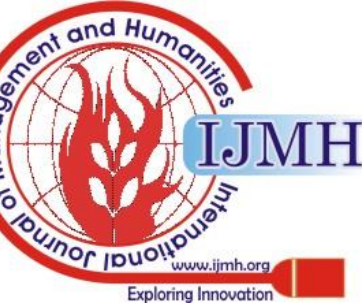


Cap Coast II, a climate change adaptation and disaster risk reduction programme in vulnerable communities in Almora, has helped the communities adopt measures that address environmental, social and economic sustainability in rural areas with the view of creating linkages between urban and rural settlements (www.giz.de)

SEWA Bharat has been mobilizing informal women workers across Almora, Dehradun, Mussoori and Rudraprayag districts, in the hospitality sector, farmers, vendors, and artisans who collectively work together to transform their communities economically and socially. It is delivering technical training to women on organic certification, manure production, water tank installation, tulsi and quinoa production, microfinance and microenterprise, community trainers, value-addition through spice grinding and packaging etc. (http://sewabharat.org).

\section{BUILDING LONG TERM RESILIENCE}

Key recommendation to build long term resilience are following:

- Creation of Farmers Interest Groups, Self Help Groups for integrated farming;

- Production and use of bio-fertilizer/manure/pesticide to reduce cost, soil degradation and increase soil nutrient;

- Systematic rice intensification programme training to farmers;

- Making of Pine needle briquettes to serve as green alternative fuel thereby avoiding forest fires, encouraging Briquette stoves that use green fuel to reduce carbon emission;

- Group farming, cash crops(turmeric, ginger, chip potatoes etc.), enhancing soil fertility, building irrigation canals, high quality seeds and scientific farm techniques;

- Afforestation, soil conservation and improving biodiversity;

- Sustainable land use with good mix of agro-forestry;

- Water catchment area protection;

- Plantation of Fruit bearing trees and development of fruit based product manufacturing to improve income. It also improves carbon sinks providing moisture and nutrient to soil;

- Cattle rearing, health check-ups for livestock, livestock insurance, fodder grass and trees plantation as alternate livelihood sources;

- Poultry, goat rearing, carpentry, iron-smithy, basket weaving, tailoring related vocational training etc.

- Promotion of Medicinal and Aromatic plants (tejpatta, satavari, ashwagandha, brahmi, rosemary, amla, harad, baheda and sarpagandha etc) at higher altitudes;

(www.inhereindia.org)

- Resources and space for adaptation should become a central development imperative. (Source: Adger et.al, 2003).

- Analysis of climate change risks to project activities, stakeholders and outcomes. Accordingly modification in project designs or implementation plans. (www.careclimatechange.org).

- Adaptation programmes should include increasing farmers' knowledge of predictable weather events with the use of technology, diversifying cropping patterns to better withstand droughts and/or floods, and targeting irrigation systems to combat water insecurity. (http://actionclimate.today).

\section{CONCLUSION}

Based on the study of the existing efforts and practices pertaining to climate resilience in Almora, need for certain specific interventions emerge, which may be given priority at the State and Local Government for better and sustainable communities in Almora:

$>$ There is need to work with the local industries and the society as a whole in synergy, by the Government, to provide the younger generation with better vocational study/training options for a sustainable future;

$>$ There is need to promote diversified agricultural practices with less risks involved and good price back for investments made;

$>$ Options for growth in tourism sector and agriculture extension services sector may be explored and promoted to curb population migration from hilly terrain for alternate livelihood elsewhere;

$>$ There is need to make available low interest loan options for small industry set ups;

$>$ Skill Development Training and guidance for managing businesses are required to be promoted;

$>$ Communities may be educated about new adaptation techniques among the communities;

$>$ There is a need to operationalize the Urban Climate Resilience

Policy framework in Almora;

$>$ Preparation of a detailed risk profile of the state in terms of climate impacts and extreme events in the context of urban areas and vulnerability analysis of cities, city resilience strategy \& region-specific resilience plans may be taken up in the State of Uttarakhand and specially in Almora;

$>$ There is a need to accumulate and analyse the climatic data and climate projections of the Almora region;

$>$ Setting up of institutionalized plan and multi-level engagement of stakeholders need to be promoted;

$>$ Suitable finances may be made available for urban resilience and capacity building of local communities;

$>$ Projects being undertaken may be analyzed to make them climate proof along with suitable measure for mechanisms of climate financing in every programme and its implementation.

$>$ Further detailed micro level vulnerability study and village level planning based on climate and disaster risk vulnerability may also be undertaken to scale up the benefits of climate resilience at local level.

\section{ACKNOWLEDGEMENTS}

Authors gratefully acknowledge the support and encouragements from Prof. Mahesh Verma, VC-GGSIPU, Major General Manoj Kumar Bindal, Executive Director NIDM and Prof. N C Gupta, Dean, USEM-GGSIPU. Support from District Administration - Almora, Uttarakhand Government and GEAG-Gorakhpur is also gratefully acknowledged. 


\section{REFERENCES}

1. Sendai Framework for Disaster Risk Reduction (SFDRR) 2015-2030;

2. Government of Uttarakhand (2014): Station Action Plan on Climate Change (SAPCC);

3. District Administration, Almora (2018-19): District Disaster Management Plan (DDMP);

4. District Administration, Almora: Tehsil Map (2019)

5. Institute for Himalayan Environment Research and Education (INHERE) (1982): Adaptation Process - Sustainable Development Models, www.inhereindia.org.

6. Centre for Ecology Development and Research (CEDAR) (2015): Climate Change in Uttarakhand - Current State of Knowledge and Way Forward, www.cedarhimalaya.org.

7. Indian Council for Research on International Economic Relations (2008): Development Strategy for the Hill Districts of UttarakhandWorking Paper No 217.

8. Sharma S.( June 4, 2017): Impact of climate change on water resources in Uttarakhand, Published in Times of India.

9. Integrating Climate Change Concerns into Disaster Management and Development Planning - The case of Almora, Uttarakhand (2016): Published by Gorakhpur Environmental Action Group (GEAG), Institute for Social and Environmental Transition (ISET) International and Climate and Development Knowledge Network (CDKN).

10. Indian Journal of Natural Products and Resources (March,2010): Native Plant Genetic Resources and traditional food of Uttarakhand Himalaya for sustainable food security and livelihood, Vol 1(1), pp 89-96.

11. National Institute of Rural Management, Anand (August, 2013): Pathways to Climate Resilient Livelihoods in the Himalayan River Basin, New Delhi Workshop proceedings.

12. Piyoosh Rautela, Bhavna Karki (2015): Impact of Climate Change on Life and Livelihood of Indigenous People of Higher Himalaya in Uttarakhand, India, Published in the American Journal of Environmental Protection.

13. Planning Commission (2013): Report of The Committee to Study Development in Hill States arising from Management of Forest Lands with Special Focus on Creation of Infrastructure, Livelihood and Human Development.

14. TERI (2016): Road map for mainstreaming urban climate resilience in Uttarakhand, Rockfeller foundation, www.teriin.org.

15. Shared Learning Dialogues (SLDS) (2016): First Round Vulnerability Analysis by Gorakhpur Environmental Action Group (GEAG), National Institute of Disaster Management (NIDM), Institute for Social and Environmental Transition (ISET) International and Climate and Development Knowledge Network (CDKN).

16. Shared Learning Dialogues (SLDS) (2016): Second Round - Resilient Options by Gorakhpur Environmental Action Group (GEAG), National Institute of Disaster Management (NIDM), Institute for Social and Environmental Transition (ISET) -International and Climate and Development Knowledge Network (CDKN).

17. Times of India (August 18, 2017): Submission of Report by M/Agriculture to the Parliamentary Committee.

18. www.giz.de: Up-scaling Community Based Approaches to Climate Change Adaptation: Almora, Uttarakhand, by deutsche gesellschaft für internationale Zusammenarbeit (giZ) gmbh,

19. Neil Adger, Saleemul Haq, Katrina Brown, Declan Conwaya and Mike Hulmea (2003): Adaptation to climate change in the developing world, Progress in Development Studies 3, pp. 179-195.

20. https://www.ifad.org/evaluation/reports/ppa/tags/india/1226/7951380.

21. https://ilsp.in/about.html.

22. http://www.careclimatechange.org/tk/integration/en/about_the_toolkit /what_do_we_mean_by.html.

23. http://chimalaya.org/2012/10/26/community-adaption-practices-inuttarakhand-himalayas-of-india-case-study/.

24. http://www.actiononclimate.today/act-on-information/mitigationadaptation-and-resilience-climate-terminology-explained/.

25. http://www.indiaris.nrsc.gov.in/wrpinfo/index.php?title=Uttarakhand\#Climate.

26. http://sewabharat.org/across-india/sewa-in-uttarakhand/\#almora. 